OPEN ACCESS

Edited by:

Gian Mauro Manzoni,

University of eCampus, Italy

Reviewed by:

Katie Moraes de Almondes,

Federal University of Rio Grande do

Norte, Brazil

Michael Grady Wheaton,

Columbia University, United States

${ }^{*}$ Correspondence:

Mariola Bidzan

mariola.bidzan@ug.edu.p

Specialty section:

This article was submitted to

Psychopathology,

a section of the journal

Frontiers in Psychology

Received: 16 April 2020 Accepted: 17 November 2020

Published: 23 December 2020

Citation:

Bidzan M, Bidzan-Bluma I,

Szulman-Wardal A, Stueck $M$ and Bidzan M (2020) Does Self-Efficacy

and Emotional Control Protect Hospital Staff From COVID-19 Anxiety and PTSD Symptoms? Psychological

Functioning of Hospital Staff After the Announcement of COVID-19

Coronavirus Pandemic.

Front. Psychol. 11:552583.

doi: 10.3389/fpsyg.2020.552583

\section{Does Self-Efficacy and Emotional Control Protect Hospital Staff From COVID-19 Anxiety and PTSD Symptoms? Psychological Functioning of Hospital Staff After the Announcement of COVID-19 Coronavirus Pandemic}

\author{
Monika Bidzan1, Ilona Bidzan-Bluma², Aleksandra Szulman-Wardal2,3, Marcus Stueck ${ }^{4}$ \\ and Mariola Bidzan ${ }^{2 *}$
}

\footnotetext{
${ }^{1}$ Medical University of Gdansk, Gdańsk, Poland, ${ }^{2}$ University of Gdansk, Gdańsk, Poland, ${ }^{3}$ The Specialist Hospital in Koscierzyna, Koscierzyna, Poland, ${ }^{4}$ DPFA Academy of Work and Health, Leipzig, Germany
}

Objectives: The aim of this study was to assess coronavirus disease 2019 (COVID-19) anxiety and posttraumatic stress disorder (PTSD) symptoms in the hospital staff, as well as to identify protective factors of COVID-19 anxiety once the coronavirus pandemic was announced in Poland.

Methods: 90 healthcare workers from the hospital in Poland completed validated selfreport questionnaires assessing self-efficacy, emotional control, and PTSD symptoms; a questionnaire assessing COVID-19 anxiety; and a socio-demographic questionnaire. A multiple linear regression was conducted to assess the effects of gender, being directly vs indirectly exposed to patients, and general self-efficacy on COVID-19 anxiety.

Results: The analysis showed that female $(\beta=-0.271, p<0.01)$ healthcare professionals indirectly exposed to patients $(\beta=-0.336, p<0.01)$ and those who reported lower levels of general self-efficacy $(\beta=-0.295, p<0.01)$ have a stronger tendency to experience COVID-19 anxiety $\left[R^{2}=0.301, F(3,89)=12.34, p<0.01\right]$.

Conclusion: The findings show the importance of self-efficacy for dealing with COVID19 anxiety. The internal coping strategies should be introduced to healthcare workers.

Keywords: COVID-19, healthcare workers, disaster, fears, protective factors

\section{INTRODUCTION}

Coronavirus disease 2019 (COVID-19) is thought to be a highly infectious disease. It is primarily transmitted by respiratory droplets and has a similar incubation time and generation time as SARS coronavirus (SARS-CoV) (Wilder-Smith and Freedman, 2020). The first case of COVID-19 had been reported in Wuhan City, China, on 9 January 2020 (Lu et al., 2020). Despite Wuhan City 
being locked down within 2 weeks after COVID-19 had been reported, the novel virus has soon reached other provinces in China and neighboring countries. By 11 March 2020, the World Health Organization (WHO) declared COVID-19 a global pandemic. At the time we started writing this article (13 April 2020), there were over 1.4 million confirmed cases of COVID19 and 116,052 deaths globally; at the time we finished it (12 June 2020), there are 7,616,598 confirmed cases of COVID19 and 424,227 deaths globally (Khasawneh, 2020; Medonet, 2020; Worldometers, 2020). 215 countries are affected by the novel coronavirus (Worldometers, 2020), including Poland, where the first case of COVID-19 had been reported on 4 March 2020, and the COVID-19 pandemic had been announced on 20 March 2020.

It is worth bearing in mind that since the Ebola virus pandemic back in 1976, COVID-19 pandemic has been the one and only pandemic outbreak from among 25 recognized EVD pandemics, which "spread all over the world" and fulfilled the criteria of a "pandemic" (Espinola et al., 2016; Rabelo et al., 2016; Shultz et al., 2016). Widespread outbreak of COVID-19 has frightened and alerted the whole world. This might be partly due to media, which has been constantly updating the global population with the news on COVID-19 outbreak. Fear behaviors in a situation of a disaster spread rapidly and contagiously (Espinola et al., 2016; Shultz et al., 2016), which has resulted in a global panic (Vellingiri et al., 2020). In Poland, the "pandemic fear" had started before the pandemic was announced. For example, "panic buying" (Sim et al., 2020) had started before the lock-down on 11 March 2020.

COVID-19 affects both the physical and mental health of the affected population (North et al., 2004; Khan et al., 2020; Lai et al., 2020; Super et al., 2020). During a disaster, mental disorders are often diagnosed in an affected population, such as adjustment disorders, depression, posttraumatic stress disorder (PTSD), anxiety disorders, non-specific somatic symptoms, and substance abuse (North, 2002; North et al., 2004; Liu et al., 2006; Tsai et al., 2007; Frankenberg et al., 2008; Hollifield et al., 2008; Wu et al., 2009; Math et al., 2015; Bidzan-Bluma et al., 2020; Lai et al., 2020; Khasawneh, 2020; Rajkumar, 2020; Super et al., 2020).

Researchers have assigned PTSD as the signature diagnosis among post-disaster mental morbidity (North, 2003; Math et al., 2015; Ogińska-Bulik and Kraska, 2017; Moghadam et al., 2020). The main PTSD symptoms are intrusion (reliving the traumatic event over and over again in dreams or memories), avoidance (of feelings, conversations, stimuli, or actions related to the event experienced), and agitation (trouble with focusing, but also falling asleep, general irritability, strong emotional reactions in response to sudden stimuli, constant sense of threat) (World Health Organization [WHO], 1992; Juczyński and Oginìska-Bulik, 2009; Juczyński, 2012; Rybojad and Aftyka, 2018). According to DSM-5 (2013), diagnosis of PTSD includes experiencing repeated or extreme exposure to aversive details of the traumatic events, occurring usually during performance of professional duties. In the case of disasters, this mainly refers to the emergency services (police, military, fire fighters, paramedics) (James, 2011a,b; Ogińska-Bulik, 2013, 2016; Ogińska-Bulik and Juczyński, 2016; Rybojad and Aftyka, 2018). In relation to COVID-19, this applies primarily to the medical staff providing direct help to the infected patients and those under the threat of developing the disease. However, the incidence of PTSD in these groups is highly diversified and depends on factors such as the scope of exposure, social support, and training (James, 2011a,b; Ogińska-Bulik, 2013; Ogińska-Bulik and Juczyński, 2016). In particular, demographic characteristics such as age and gender are associated with different rates of PTSD, with younger people and women more likely to develop this stress disorder. Interpersonal and psychological characteristics of the individual, such as social support and self-esteem, have also been implicated in the onset and course of PTSD (Adams and Boscarino, 2006).

The medical personnel, including paramedics, physicians, nurses, obstetricians, nursing aids, psychologists, but also medical analysts, radiology professionals, and cleaning, transport, and technical staff, are all involved in a particular way in preventing the consequences of COVID-19 pandemic and performing crisis interventions. Healthcare workers should be regarded as a highly exposed group with a higher risk of psychiatric symptoms during the COVID-19 pandemic. The risk factors among healthcare workers include female gender and being a frontline worker among others (Vindegaard and Benros, 2020).

Among Chinese healthcare workers exposed to COVID-19 (from clinics or wards for patients with COVID-19 in multiple regions of China), women, nurses, individuals living in Wuhan, and frontline healthcare workers have been shown to have a high risk of developing unfavorable mental health outcomes. They reported experiencing symptoms of depression, anxiety, insomnia, and distress, especially female nurses (Lai et al., 2020).

Personal and social resources are constituting means of efficient coping with a threat. Studies have confirmed a positive meaning of the possibility to express emotions when faced with a disaster. Personal resources of an individual play a crucial role in emotional expression. These include the sense of personal control, self-efficacy, resourcefulness, sense of humor, optimism, valuation, and coping with distressing events (Adams and Boscarino, 2006; Doliński, 2006; Ranieri et al., 2020). Medical profession representatives are expected to have psychological resilience, whose significant aspect is experiencing emotions and expressing them in a certain way. Experiencing emotions is usually accompanied by somatic changes, mimic and pantomimic expressions, and specific behavior (Da̧browska-Chołostiakow and Kocbach, 2018). Emotions are related to self-control, which is defined as demonstrating a behavior consistent with the norms accepted by an individual or with social norms. Selfcontrol involves reactions initiated by a subject, by means of which he achieves congruence among his own emotional states, thought and affective feelings, and the accepted internal norms (internalized rules of functioning) or the external ones (socially approved rules) (Wagner and Heatherton, 2013). It is emphasized in the literature that suppressing emotions is an unfavorable phenomenon, because it may lead to intensification of the experienced emotions or their lingering in the form of emotional tension (Doliński, 2006).

Self-efficacy allows to assess the situations accurately and seek efficient ways of coping with the encountered difficulties and obstacles (Juczyński, 2000, 2012). People with high self-efficacy can maintain relatively stable emotions even under pressure 
(Bihlmaier and Schlarb, 2016). Self-efficacy also increases concentration and self-control (Przepiórka et al., 2019; Xiao et al., 2020). Low sense of self-efficacy is related to anxiety and sense of helplessness, while high sense of self-efficacy is related to the higher level of positive emotions (these persons assess distressing stimuli more often as a challenge than a threat), which favors taking up challenges, defining aims, and achieving successes in fulfilling them (Maddux and Lewis, 1995; Juczyński, 2012; Schwarzer, 2015).

Currently, there are no studies conducted on the psychological resources, including emotional control and self-efficacy, of healthcare workers during the COVID-19 pandemic. At the time of the COVID-19 pandemic, the workplace environment is not supportive in Polish hospitals because Polish healthcare centers suffer from acute lack of the necessary protective measures, including protective masks, disposable gloves, protective coats and coveralls, and disinfecting liquids. This makes healthcare workers particularly vulnerable to developing unfavorable mental health outcomes, including PTSD. Based on the previous studies, it seems that the sense of self-efficacy and emotional control (of anger, anxiety, depression) may be related to the functioning of the hospital staff, including the intensity of PTSD, after the COVID-19 pandemic was announced.

The aim of this study was to assess the psychological resources, including coping self-efficacy and emotional control (of anger, anxiety, depression) of hospital staff with reference to the coronavirus anxiety and PTSD symptoms after the coronavirus pandemic was announced.

This is the first study to investigate the psychological resources of healthcare workers during the COVID-19 pandemic, and the first study to assess psychological outcomes of the COVID-19 pandemic on healthcare workers in Europe.

\section{MATERIALS AND METHODS}

\section{Study Group}

The study group consisted of 90 healthcare workers from a district hospital in Kościerzyna, Pomeranian region, Poland. The staff included paramedics, physicians, obstetricians, nursing aids, psychologists, medical analysts, radiology specialists, cleaning, transport, and technical crews. Descriptive characteristics of the study participants are described in Table $\mathbf{1}$.

\section{Research Procedure}

The study was conducted in the hospital on 22 March 2020-2 days after the coronavirus pandemic had been announced in Poland. Considering that the lockdown-type control measures in Poland started before the pandemic was announced (first lockdown-type control measures had started on 10 March 2020), the panic had also started well before the pandemic was announced.

The research project was reviewed and approved positively by the Ethical Committee (decision no. 29/2020) at the Institute of Psychology at the University of Gdańsk, Poland. Participants in the current study were obtained with a cooperation of a gatekeeper, which allowed access to the hospital. Participants
TABLE 1 | Descriptive characteristics of the study participants.

\begin{tabular}{lr}
\hline Variables & $\boldsymbol{N}=\mathbf{9 0}$ \\
\hline Gender & $N=23(25.6 \%)$ \\
Males & $N=67(74.4 \%)$ \\
Females & \\
Direct vs indirect exposure to patient & $N=66(73.3 \%)$ \\
Direct & $N=24(26.7 \%)$ \\
Indirect & \\
Specialization & $N=48(53.3 \%)$ \\
Yes & $N=42(46.7 \%)$ \\
No & $M=45.66$ \\
Age & $(S D=9.70)$ \\
Number of years in the profession & $M=19.373$ \\
& $(S D=11.29)$ \\
\hline
\end{tabular}

included in the study were hospital workers, without any psychiatric diagnosis in the past to the present, who agreed to participate in the study. Exclusion criteria included DSM-5 psychiatric diagnoses (American Psychiatric Association, 2013) and taking psychotropic medications. Psychiatric diagnoses were performed by a psychiatrist.

Recruitment of the participants involved a general conversation about the pandemic, which was meant to encourage the respondent to take part in the study. After agreeing to take part in the study, individual meetings were scheduled. During the meetings, participants were asked to fill out the questionnaires.

The following research tools were used:

1. Author's own survey including socio-demographic data

2. Author's own three-item anxiety scale concerning anxiety about coronavirus.

The respondents were asked to assess, on a scale of $0-10$, how strong are their fears of COVID-19 in relation to: worries about themselves (I am worried about myself), worries about loved ones (I am worried about my loved ones), and fear of losing their job (I am worried about losing my job and poverty). Responses for all three items were summed up to create a composite measure in which higher scores reflect greater anxiety concerning the consequences of COVID-19. This is an author-designed tool, which has been standardized in relation to Hamilton Anxiety Rating Scale (HAM-A). Scores of 15 and above correspond with HAM-A scores of 18 and above, which is a commonly used cutoff score of anxiety disorders in clinical studies (Hamilton, 1959; Małyszczak et al., 1999; Kocjan, 2016).

A one-factor structure of the tool was tested via confirmatory factor analysis (CFA). Model's fit statistics show very good fit: CFI $=0.99$, RMSEA $=0.001$. Scale reliability in the current study was assessed using the Cronbach's alpha. The results of this measure equaled 0.77 .

In addition, the measurement of COVID-19 anxiety was supplemented with a single item assessing concerns about coronavirus infection, i.e., "Are you worried about catching the coronavirus?" Study participants reported their concerns on a five-point scale: (1) Definitely not; (2) Probably not; (3) Probably 
yes; (4) Yes; and (5) Definitely yes. On the scale, scores of 3 and above indicated fear of catching COVID-19; hence, we selected 3 as a cutoff score.

Considering a relatively small number of participants $(N=90)$, we used a dichotomic classification of fear of COVID-19 for both scales. For the dichotomic classification, we used the cutoff scores and assigned $0=$ no fear, $1=$ fear. This could result less likely to creation of biased estimates than are more unbalanced dichotomies (Pedhazur and Schmelkin, 1991; Borz and Döhring, 2006).

General Self-Efficacy Scale (GSES), which is a 10-item psychometric scale that is designed to assess optimistic self-beliefs to cope with a variety of difficult demands in life. The scale was originally developed in German by Jerusalem and Schwarzer (1992). The total score a person can get is between 10 and 40 points. The higher the score, the higher the self-efficacy, which translates into greater self-confidence and better ability to cope with a difficult situation. Sten scores 10-24 points were regarded as low, 30-40 points as high, and 25-29 points as average.

A Polish version (Juczyński, 2012) has been shown to be reliable and valid (Cronbach's alpha equaled 0.85). Additionally, scale reliability was assessed by the author using the test-retest method (after 5 weeks) and equaled 0.78 (Juczyński, 2012); in the present study, Cronbach's alpha resulted to be 0.86 .

The Courtauld Emotional Control Scale (CECS) (Polish version), which is a 22 -item questionnaire developed to measure the extent to which individuals report suppressing emotions of anger, anxiety, and depressed mood. Subscales have been shown to be consistent with these primary emotions: anger, depressed mood, and anxiety. The total emotional control index is within $21-84$ points. The higher the result, the more enhanced the suppression of negative emotions. The Polish version was found to be a reliable and valid method. The following Cronbach's $\alpha$ coefficients were obtained: for the control of anger 0.80 , depression 0.77 , anxiety 0.78 , and for the total emotional control index 0.87 (Juczyński, 2012), with our data Cronbach's alpha for the total emotional control index equaled 0.76 .

Impact Event Scale-Revised (IES-R)-Polish version (Juczyński and Oginiska-Bulik, 2009) is a self-report measure that assesses a subjective psychological distress caused by a traumatic event. The principal component analysis identified three factors
(Intrusion, Hyperarousal, and Avoidance), which are closely associated with PTSD symptoms. The cutoff point is 30 points.

The Polish version was found to be a reliable and valid method. The overall scale reliability measured with Cronbach's alpha is 0.92; in the present study, Cronbach's alpha resulted to be 0.94 .

\section{Data Analyses}

Descriptive statistics were computed for the characteristics of the sample consisting of frequencies and percentages for categorical variables and means and standard deviations (SDs) for scale variables (Table 1). Parametric assumptions were tested before conducting parametric tests. Differences in levels of anxiety concerning the consequences of COVID-19 between males and females; professionals directly vs indirectly exposed to patients; and professionals with vs without specialization were assessed via $t$-test.

Before analyzing the correlation between variables, we assessed the normality of the distribution of variables on the basis of skewness and kurtosis (see Table 2).

The criterion set was $<2.0$.

As there were no clear deviations from the normal distribution, we used the Pearson's $r$ coefficient. Bivariate associations between study variables were assessed via Pearson's correlation coefficient $r$ (Table 2).

A multiple linear regression was conducted to ascertain the effects of gender, being directly vs indirectly exposed to patients, and general self-efficacy on the anxiety concerning the consequences of COVID-19. We followed the hypothesis, and CECS is not the significant predictor, so we did not include it in the regression model.

\section{RESULTS}

The majority of the respondents $(N=62 ; 68.9 \%)$ reported being worried of catching COVID-19. The majority of the respondents ( $N=84,93 \%)$ also demonstrated a subjective distress caused by COVID-19 (only six individuals did not report them). The mean General Self-Efficacy GSES was relatively high in the studied group of respondents. The mean score of Control of Negative Emotion CECS suggests that the respondents had an average suppression of negative emotions. Table 2 contains descriptive

TABLE 2 | Means, standard deviations, and correlation matrix of the study variables.

\begin{tabular}{|c|c|c|c|c|c|c|c|c|c|c|}
\hline Variables & $M$ & $S D$ & Skew. & Kurt. & 1 & 2 & 3 & 4 & 5 & 6 \\
\hline 1. Age & 45.66 & 9.70 & -0.51 & -0.32 & & & & & & \\
\hline 2. Number of years in the profession & 19.37 & 11.29 & 0.05 & -0.85 & $0.790^{\star *}$ & & & & & \\
\hline 3. Fear of catching COVID-19 & 3.97 & 1.09 & -0.63 & -0.93 & 0.031 & 0.061 & & & & \\
\hline 4. Anxiety concerning the consequences of COVID-19 & 19.49 & 8.10 & -0.20 & -1.06 & 0.114 & -0.040 & $0.478^{\star \star}$ & & & \\
\hline 5. GSES & 30.66 & 3.82 & 0.66 & 1.45 & -0.040 & -0.090 & $-0.331^{\star \star}$ & $-0.322^{\star \star}$ & & \\
\hline 6. CECS overall & 49.74 & 9.31 & 0.37 & -0.03 & $-0.304^{\star *}$ & -0.160 & -0.040 & 0.030 & -0.160 & \\
\hline 7. PTSD overall (IES-R) & 62.16 & 18.21 & 0.01 & -0.70 & $0.239^{\star}$ & 0.209 & $0.488^{\star \star}$ & $0.348^{\star \star}$ & $-0.253^{\star}$ & -0.140 \\
\hline
\end{tabular}

$N=90$.

${ }^{*} p<0.05$.

$* * p<0.01$. 
statistics and a correlation matrix (Pearson's correlation) of the variables studied.

Further analysis showed that women reported higher levels of anxiety concerning the consequences of COVID-19 $(M=20.82$, $S D=7.53)$ than men $(M=15.61, S D=8.23), t(88)=2.76$, $p<0.01$; the difference is moderate (Cohen's $d=0.66$ ) (equal variance assumed $F=0.24, p=0.63$ ). Contrary to expectations, healthcare professionals directly exposed to patients reported lower levels of anxiety concerning the consequences of COVID$19(M=17.40, S D=7.92)$ than those who were indirectly exposed to patients $(M=24.11, S D=6.53), t(88)=3.92$, $p<0.0$; the difference was high (Cohen's $d=0.92$ ) (equal variance assumed $F=1.20, p=0.23)$. Healthcare workers with specialization obtained significantly lower mean scores for anxiety concerning the consequences of COVID-19 $(M=16.27$, $S D=7.32)$ than workers without specialization $(M=22.57$, $S D=7.67), t=3.98, p<0.01$; the difference was high (Cohen's $d=0.84$ ) (equal variance assumed $F=0.31, p=0.58$ ). There were no significant differences between healthcare workers with and without specialization when PTSD symptoms overall score was compared $(t=1.56, p=0.12)$.

\section{Linear Regression Analysis}

A multiple linear regression was conducted with SPSS Statistics to ascertain the effects of gender, being directly vs indirectly exposed to patients, and general self-efficacy on the anxiety concerning the consequences of COVID-19. The results of multiple regression analyses showed a significant main effect of all predictors on the anxiety concerning the consequences of COVID-19, suggesting that female $(\beta=-0.271, p<0.01)$ healthcare professionals indirectly exposed to patients $(\beta=-0.336, p<0.01)$, who reported lower levels general self-efficacy $(\beta=-0.295, p<0.01)$ have a stronger tendency to respond with anxiety regarding the consequences of COVID-19 $\left[R^{2}=0.301, F(3,89)=12.34\right.$, $p<0.01]$.

\section{DISCUSSION}

The aim of this study was to assess the psychological resources, including coping self-efficacy and emotional control (of anger, anxiety, depression) of hospital staff with reference to the coronavirus anxiety and PTSD symptoms, once the coronavirus pandemic was announced in Poland. The study was conducted shortly after the restriction period in Poland has started, and it investigated the subjective assessment of COVID-19 threat and PTSD symptoms in the hospital staff, as well as identified protective factors of fear of COVID-19.

The COVID-19 pandemic was perceived by the group of hospital personnel (medical, technical, and maintenance staff) as a genuine threat. Majority of the respondents were worried of catching COVID-19. According to the stressadaptation model, the experience of fear and stress is defined as a universally experienced response to extraordinary life circumstances (Maudner et al., 2003; Valdez and Nichols, 2013). The fear of catching the coronavirus may also stem from the high awareness of the hospital staff that the virus may be absorbed by the cells of the mucus membrane in the eyes, nose, cheek-after which it changes its genetic code, multiplies, and transforms its own cells into the cells of the intruder. The virus is invisible and may be everywhere-in a patient's breath, on his clothes, items in his possession, and on everything he touched. It is easily transmittable. The hospital personnel might thus perceive the virus as a genuine invisible threat to them and all persons they get in touch with (including their close friends and relatives). This could explain their real fear of coronavirus. The perception of one's own situation as threatening may deepen insecurity. Usually, at the time of pandemic, infection monitoring procedures and public health recommendations are modified frequently. The changes may be introduced on a daily or even hourly basis, which explains the increased level of insecurity in the medical personnel. It seems that media broadcast also intensifies insecurity and anxiety. Research also suggests that the staff lacks both planning and strategic solutions for the community at various levels at the time of disasters, which also intensifies insecurity and anxiety when facing a threat (Roudini et al., 2017). Moreover, when faced with a disaster, individual fear behaviors spread rapidly and contagiously, among groups of persons who share the fear and observe the behaviors of each other (Espinola et al., 2016; Shultz et al., 2016). Finally, the fear of COVID-19 may also be related with stigmatization of healthcare workers, others' fear of contact with those treating patients with COVID-19 (Ramaci et al., 2020). We could observe similar fearrelated behaviors in the years 2013-2016 during the West Africa Ebola Virus Disease Outbreak (Espinola et al., 2016; Rabelo et al., 2016; Shultz et al., 2016).

Widespread outbreak of COVID-19 is associated with psychological distress and symptoms of mental illness (Bao et al., 2020; Rajkumar, 2020; Super et al., 2020; Vindegaard and Benros, 2020). Work-related mental health impairment is recognized as a real problem in the context of helping responders, including health professionals, due to adverse health outcomes after a severe disaster (Neria et al., 2011; Farooqui et al., 2017; Nukui et al., 2018). Recent studies have shown that among healthcare workers depression and anxiety rates were higher (Chen et al., 2020; Mo et al., 2020) compared to administrative staff ( $\mathrm{Lu}$ et al., 2020; Zhang et al., 2020) and non-frontline workers (Liang et al., 2020; Vindegaard and Benros, 2020), during the COVID19 pandemic (Xu et al., 2020). We observed differences between workers directly exposed to patients and those indirectly exposed to patients. Despite the fact that workers directly exposed to patients are more prone to being directly exposed to COVID19 , they experienced coronavirus-related worries less frequently than workers indirectly exposed to patients, as well as healthcare workers with specialization obtained significantly lower mean scores for anxiety concerning the consequences of COVID-19 than workers without specialization. This could be explained by their awareness of having a job which is strongly socially desirable, as well as awareness of their own skills and the sense of self-efficacy. Some research has shown contradicting results, i.e., female nurses in Wuhan working in the front-line medical staff were twice more likely to suffer anxiety and depression than the non-clinical staff (Lai et al., 2020; Lu et al., 2020). In those studies, however, studied nurses have had close contact 
with COVID-19 patients. In the present study, the medical staff could potentially have had a direct contact with patients infected with COVID-19, yet there were no cases of COVID-19 registered in the hospital.

In the current study, gender was another variable that turned out to be a significant predictor to respond with anxiety regarding the consequences of COVID-19. Some studies have revealed that female gender and younger age are some of the risk factors of anxiety (Norris et al., 2002; Frankenberg et al., 2008; Math et al., 2015; Sohrabizadeh et al., 2016; Vindegaard and Benros, 2020). Younger persons and women are also more likely to develop that stress disorder when faced with a disaster (Adams and Boscarino, 2006). Similarly, disaster rescue workers are at high risk of developing psychiatric morbidity (Stellman et al., 2008).

In the current study, the vast majority of the participants (apart from six respondents) declared PTSD symptoms. A mass threat is a potentially traumatic event (PTE) that threatens or overtly endangers the physical and/or psychological health, well-being, and integrity of a population and that is perceived and experienced, both individually and collectively, by persons comprising the population at risk. PTEs, regardless of whether they result in physical harm, have the capacity to produce psychological distress and, with severe or prolonged exposure, PTSD (Espinola et al., 2016). It is worth emphasizing that not all respondents declared being anxious of COVID-19, and not all of them had the PTSD symptoms. Although researchers have assigned the PTSD as the signature diagnosis among postdisaster mental morbidity, the incidence of PTSD reported in literature ranges from 4 to 60\% (Pietrzak et al., 2012; Brooks et al., 2019). The level of PTSD symptoms was correlated with age, sense of self-efficacy, and fear of catching COVID19 and anxiety concerning the consequences of COVID-19. There was no significant relationship between gender and PTSD symptoms scores.

Nowadays, the workplace environment is not supportive in Polish hospitals, especially at the time of COVID-19 pandemic, because currently Polish healthcare centers suffer from acute lack of the necessary protective measures, including protective masks, disposable gloves, protective coats and coveralls, and disinfecting liquids. We assumed that emotional control would be a significant factor protecting against the PTSD symptoms and fear of COVID-19. The obtained results do not confirm this assumption. Only age negatively correlated with emotional control. Younger age supported the control of negative emotions, which could be due to greater adherence to the professional workplace norms, which favor emotional control and discourage expressing negative emotions (anger, anxiety, depression) when at work in a hospital. The control of negative emotions decreased with age. The obtained results are consistent with Averill's (2004) review. According to Averill (2004), the diversity of emotions experienced by a person results from the possession of various cognitive emotional programs of responding to events. Cognitive emotional patterns are inborn, but they develop and change under the impact of life experiences. Emotions are a kind of social role. Controlling them means being emotionally correct, which is a condition of high emotional intelligence (Averill, 2004). The fact that the hospital staff do not always control negative emotions or admit much more easily to it may be due to the general life experience growing with age. Expressing negative emotions is beneficial and recommended in various psychotherapeutic approaches (Salovey et al., 2002).

We assumed that the sense of self-efficacy will be a significant resource in the light of the COVID-19 pandemic. The GSES scores were negatively correlated with fear of catching the coronavirus as well as anxiety concerning the consequences of COVID-19. The sense of self-efficacy of hospital personnel is based primarily on their education, practical skills, and expert knowledge, so even lack of external resources, such as protective masks they have, face shields, goggles, disposable gloves, protective coats and coveralls, and disinfecting liquids, does not lower the sense of self-efficacy in all hospital staff groups. Anxiety has been shown to increase sensitivity to work pressure and the working environment and has a negative effect on self-efficacy because it reduces positive behaviors and initiative (Bandura and Adams, 1977; Miller et al., 2006; Xiao et al., 2020).

\section{Strengths}

The main strength of the study is that it was conducted 2 days after the COVID-19 pandemic had been announced in Poland, which controls the limitations that often arise in retrospective studies. Furthermore, it was conducted in a nonartificial environment-at the workplace, with direct researcherrespondent contact. The study group consisted of the staff from one hospital, who were directly, as well as indirectly, exposed to patients. Personnel not commonly involved in research, such as maintenance workers, were also included in this study.

\section{Limitations}

The limitations of this study include a sample that is limited to the personnel in only one hospital in the Pomeranian region, Poland, which makes it impossible to generalize the conclusions to hospital staff from other hospitals. Moreover, the current study investigated symptoms and/or signs of PTSD rather than PTSD. It is hence impossible to ascertain whether the respondents suffered from PTSD or only experienced the symptoms of PTSD. In order to diagnose PTSD, a full psychiatric assessment would need to be conducted.

Conducting the study just 2 days after the COVID-19 pandemic had been announced in Poland can be a strength as well as a limitation. Considering that the media broadcast has been intensifying insecurity and anxiety since the first case of COVID-19 had been reported in Wuhan City, it seems that the "coronavirus fear" in Poland had started before the pandemic was announced, yet this is only an assumption. Symptoms of PTSD usually manifest within the first 3 months after the trauma, hence not enough time might have passed for some of the respondents to manifest PTSD symptoms. It is also difficult to ascertain without a psychiatric examination whether the respondents had PTSD symptoms or acute stress disorder (ASD) symptoms. PTSD refers to the long-term aftermath of trauma (when the symptoms last longer than a month), while ASD refers 
to the initial traumatic symptoms that arise immediately after a traumatic event (Bryant et al., 2000a,b; Bryant and Harvey, 2002). PTSD can follow ASD, but it can also occur even when ASD does not develop.

\section{CONCLUSION}

The findings show the importance of self-efficacy for dealing with COVID-19 anxiety. The internal coping strategies should be introduced to healthcare workers as a part of the psychological preparation and health management to increase the psychological resilience of the hospital staff. Research has shown (Stueck, 2007, 2009; Stueck and Villegas, 2008; Stueck et al., 2019; Parker et al., 2020) that stress reduction methods combined with body orientation, e.g., breathing meditation and Autogenic Training, has a positive effect on self-efficacy. It seems that introducing a modern biocentric and psychological disaster management approach into hospitals could prepare the hospital staff to better deal with a pandemic or crisis.

\section{DATA AVAILABILITY STATEMENT}

The raw data supporting the conclusions of this article will be made available by the authors, without undue reservation.

\section{REFERENCES}

Adams, R. E., and Boscarino, J. A. (2006). Predictors of PTSD and delayed PTSD after disaster: the impact of exposure and psychosocial resources. J. Nerv. Ment. Dis. 194, 485-493. doi: 10.1097/01.nmd.0000228503. 95503.e9

American Psychiatric Association (2013). Diagnostic and Statistical Manual of Mental Disorders, 5th Edn. Washington, DC: American Psychiatric Association.

Averill, J. R. (2004). A tale of two snarks: emotional intelligence and emotional creativity compared. Psychol. Inq. 3, 228-233.

Bandura, A., and Adams, N. E. (1977). Analysis of self-efficacy theory of behavior change. Cogn. Ther. Res. 1, 287-310.

Bao, Y., Sun, Y., Meng, S., Shi, J., and Lu, L. (2020). 2019-nCoV epidemic: address mental health care to empower society. Lancet 22, e37-e38.

Bihlmaier, I., and Schlarb, A. A. (2016). Self-efficacy and sleep problems. Somnologie 20, 275-280. doi: 10.1007/s11818-016-0085-1

Bidzan-Bluma, I., Bidzan, M., Jurek, P., Bidzan, L., Knietzsch, J., Stueck, M., et al. (2020). A polish and german population study of quality of life, well-being, and life satisfaction in older adults during the COVID-19 pandemic. Front. Psychiatry 11:585813. doi: 10.3389/fpsyt.2020.585813

Borz, J., and Döhring, N. (2006). Forschungsmethoden und Evaluation für Humanund Sozialwissenschaftler [Research Methods and Evaluation for Human and Social Scientists]. Berlin: Springer.

Brooks, S. K., Dunn, R., Amlôt, R., Rubin, G. J., and Greenberg, N. (2019). Protecting the psychological wellbeing of staff exposed to disaster or emergency at work: a qualitative study. BMC Psychol. 7:78. doi: 10.1186/s40359-0190360-6

Bryant, R. A., and Harvey, A. G. (2002). Delayed-onset posttraumatic stress disorder: a prospective evaluation. Aust. NZ J. Psychiatry 36, 205-209. doi: 10.1046/j.1440-1614.2002.01009.x

Bryant, R. A., Harvey, A. G., Guthrie, R. M., and Moulds, M. L. (2000a). A prospective study of psychophysiological arousal, acute stress disorder, and posttraumatic stress disorder. J. Abnorm. Psychol. 109, 341-344. doi: 10.1037/ 0021-843X.109.2.341

\section{ETHICS STATEMENT}

The studies involving human participants were reviewed and approved by the Ethics Board for Research Projects at the Institute of Psychology, University of Gdansk, Poland. The patients/participants provided their written informed consent to participate in this study.

\section{AUTHOR CONTRIBUTIONS}

MoB and IB-B contributed to conceptualization, methodology, formal analysis, writing, and original draft preparation. AS-W contributed to conceptualization, investigation, and project administration. MS contributed to conceptualization, writing, and original draft preparation. $\mathrm{MaB}$ contributed to conceptualization, methodology, formal analysis, writing, original draft preparation, and supervision. All authors contributed to manuscript revision, read, and approved the submitted version.

\section{FUNDING}

This work was supported from statutory funds of the Institute of Psychology, University of Gdansk 530W500-D672-20.

Bryant, R. A., Moulds, M. L., and Guthrie, R. M. (2000b). Acute stress disorder scale: a self-report measure of acute stress disorder. Psychol. Assess. 12:61. doi: 10.1037/1040-3590.12.1.61

Chen, Y., Zhou, H., Zhou, Y., and Zhou, F. (2020). Prevalence of self-reported depression and anxiety among pediatric medical staff members during the COVID-19 outbreak in Guiyang. China. Psychiatry Res. 288:113005. doi: 10. 1016/j.psychres.2020.113005

Dąbrowska-Chołostiakow, K. M., and Kocbach, T. (2018). Kontrola emocji oraz kompetencje społeczne pielęgniarek i pielęgniarzy pracujących w jednostkach opieki paliatywnej - raport z badania przeprowadzonego wśród pracowników zatrudnionych na terenie województwa warmińsko-mazurskiego [Emotional control and social competence of nurses working in palliative care: a research report on workers from the Warmia and Mazury voivodeship]. Palliat. Med. Pract. 12, 97-105.

Doliński, D. (2006). “Mechanizmy wzbudzania emocji," in Psychologia, Vol. 2, ed. J. Strelau (Gdańsk: Gdańskie Wydawnictwo Psychologiczne). doi: 10.15199/48. 2015.12.23

Espinola, M., Shultz, J. M., Espinel, Z., Althouse, B. M., Cooper, J. L., Bainggana, F., et al. (2016). Fear-related behaviors in situations of mass threat. Disaster Health 3, 102-111. doi: 10.1080/21665044.2016.1263141

Farooqui, M., Quadri, S. A., Suriya, S. S., Khan, M. A., Ovais, M., Sohail, Z., et al. (2017). Posttraumatic stress disorder: a serious post-earthquake complication. Trends Psychiatry Psychother. 39, 135-143. doi: 10.1590/2237-6089-2016-0029

Frankenberg, E., Friedman, J., Gillespie, T., Ingwersen, N., Pynoos, R., Rifai, I. U., et al. (2008). Mental health in sumatra after the tsunami. Am. J. Public Health 98, 1671-1677. doi: 10.2105/ajph.2007.120915

Hamilton, M. (1959). The assessment of anxiety states by rating. Br. J. Med. Psychol. 32, 50-55. doi: 10.1111/j.2044-8341.1959.tb00467.x

Hollifield, M., Hewage, C., Gunawardena, C. N., Kodituwakku, P., Bopagoda, K., and Weerarathnege, K. (2008). Symptoms and coping in Sri Lanka 20-21 months after the 2004 tsunami. Br. J. Psychol. 192, 39-44. doi: 10.1192/bjp.bp. 107.038422

James, K. (2011a). Introduction to the special issue: terrorism, disaster, and organisational science. J. Occup. Behav. 32, 933-937. doi: 10.1002/job.758 
James, K. (2011b). The organizational science of disaster/terrorism prevention and response: theory-building toward the future of the field. J. Occup. Behav. 32, 1013-1032. doi: $10.1002 /$ job.782

Jerusalem, M., and Schwarzer, R. (1992). "Self-efficacy as a resource factor in stress appraisal processes," in Self-Efficacy: Thought Control of Action, ed. R. Schwarzer (Washington, DC: Hemisphere), 195-213. doi: 10.1016/j.obhdp.2012.06.009

Juczyński, Z. (2000). Poczucie własnej skutecznosìci: teoria i pomiar [Self-efficacy: theory and measurement]. Folia Psychol. 4, 11-23.

Juczyński, Z. (2012). NPPPZ- PODRÊCZNIK- Narzêdzia Pomiaru w Promocji $i$ Psychologii Zdrowia [NPPPZ- HANDBOOK - Measurement Tools in Promotion and Health Psychology]. Warszawa: Pracownia Testów Psychologicznych Polskiego Towarzystwa Psychologicznego Sp. z o.o.

Juczyński, Z., and Ogińska-Bulik, N. (2009). Pomiar zaburzenì po stresie traumatycznym - polska wersja Zrewidowanej Skali Wpływu Zdarzenì [Measurement of post-traumatic stress disorder - Polish version of Impact Event Scale-Revised]. Psychiatria 6, 15-25.

Khan, S., Siddique, R., Xue, A., Ali, M., and Nabi, G. (2020). Novel coronavirus, poor quarantine, and the risk of pandemic. J. Hosp. Infect. 104, 449-450. doi: 10.1016/j.jhin.2020.02.002

Khasawneh, M. (2020). The effect of the spread of the new COVID-19 on the psychological and social adaptation of families of persons with disabilities in the Kingdom of Saudi Arabia. Health Psychol. Rep. (in press). doi: 10.5114/hpr. 2020.99003

Kocjan, J. (2016). Short health anxiety inventory (SHAI)-Polish version: evaluation of psychometric properties and factor structure. Arch. Psychiatry Psychother. 3, 68-78. doi: 10.12740/APP/64276

Lai, J., Ma, S., Wang, Y., Cai, Z., Hu, J., Wei, N., et al. (2020). Factors associated with mental health outcomes among health care workers exposed to coronavirus disease 2019. JAMA Netw. Open 3:e203976. doi: 10.1001/jamanetworkopen. 2020.3976

Liang, Y., Chen, M., Zheng, X., and Liu, J. (2020). Screening for Chinese medical staff mental health by SDS and SAS during the outbreak of COVID-19. J. Psychosom. Res. 133:110102. doi: 10.1016/j.jpsychores.2020.110102

Liu, A., Tan, H., Zhou, J., Li, S., Yang, T., and Wang, J. (2006). An epidemiologic study of posttraumatic stress disorder in flood victims in Hunan China. Can. J. Psychiatry 51, 350-354. doi: 10.1177/070674370605100603

Lu, W., Wang, H., Lin, Y., and Li, L. (2020). Psychological status of medical workforce during the COVID-19 pandemic: a cross-sectional study. Psychiatry Res. 288:112936. doi: 10.1016/j.psychres.2020.112936

Maddux, J. E., and Lewis, J. (1995). "Self-efficacy and adjustment. Basic principles and issues," in Self-Efficacy, Adaptation and Adjustment: Theory, Research and Application, ed. J. E. Maddux (New York, NY: Plenum Press), 37-68. doi: 10.1007/978-1-4419-6868-5_2

Małyszczak, K., Kiejna, A., and Grusiak, M. (1999). Struktura czynnikowa Skali Leęku Hamiltona [Factorial structure of the hamilton anxiety rating scale]. Psychiatr. Pol. 32, 771-779.

Math, S. B., Nirmala, M. C., Moirangthem, S., and Kumar, N. C. (2015). Disaster management: mental health perspective. Indian J. Psychol. Med. 37, 261-271. doi: 10.4103/0253-7176.162915

Maudner, R., Hunter, J., Vincent, L., Bennett, J., Peladeau, N., Leszcz, M., et al. (2003). The immediate psychological and occupational impact of the 2003 SARS outbreak in a teaching hospital. CMAJ 168, 1245-1251.

Medonet (2020). Zasiêg koronawirusa COVID-19 [MAPA aktualizacja 27.11.2020]. Available online at: https://www.onet.pl/?utm_source=poczta.wp.pl_viasg_ medonet\&utm_medium=referal\&utm_campaign=leo_automatic\&srcc=ucs\& pid $=40401004-\mathrm{e} 4 \mathrm{e} 8-4 \mathrm{c} 30-8 \mathrm{e} 7 \mathrm{c}-\mathrm{cff} 4 \mathrm{c} 747 \mathrm{c} 277$ \&sid $=4 \mathrm{e} 9 \mathrm{~b} 6959-4 \mathrm{f} 88-4 \mathrm{e} 8 \mathrm{~b}-9613-$ 65de7438fe5a\&utm_v=2 (accessed on 13 April 2020)

Miller, R. L., Pallant, J. F., and Negri, L. M. (2006). Anxiety and stress in the postpartum: is there more to postnatal distress than depression? BMC Psychiatry 6:12. doi: 10.1186/1471-244X-6-12

Mo, Y., Deng, L., Zhang, L., Lang, Q., Liao, C. H., Wang, N., et al. (2020). Work stress among Chinese nurses to support Wuhan for fighting against the COVID-19 epidemic. J. Nurs. Manage. 28, 1002-1009. doi: 10.1111/jonm.13014

Moghadam, S., Kazemi, R., Taklavi, S., and Naeim, M. (2020). Comparing the effectiveness of eye movement desensitization reprocessing and cognitive behavioral therapy in reducing post traumatic stress disorder. Health Psychol. Rep. 8, 31-37. doi: 10.5114/hpr.2019.92305
Neria, Y., DiGrande, L., and Adams, B. G. (2011). Posttraumatic stress disorder following the September 11, 2001, terrorist attacks: a review of the literature among highly exposed populations. Am. Psychol. 66, 429-446. doi: 10.1037/ a0024791

Norris, F. H., Friedman, M. J., Watson, P. J., Byrne, C. M., Diaz, E., and Kaniasty, K. (2002). 60,000 disaster victims speak: Part I. An empirical review of the empirical literature, 1981-2001. Psychiatry 65, 207-239. doi: 10.1521/psyc.65. 3.207.20173

North, C. S. (2002). Somatization in survivors of catastrophic trauma: a methodological review. Environ. Health Perspect. 110(Suppl. 4), 637-640. doi: 10.1289/ehp.02110s4637

North, C. S. (2003). "Psychiatric epidemiology of disaster responses," in Trauma and Disaster, Responses and Management, Review of Psychiatry Series, Vol. 22, eds R. J. Ursano and A. E. Norwood (Virginia: American Psychiatric Publishing, Inc.), 37-62.

North, C. S., Kawasaki, A., Spitznagel, E. L., and Hong, B. (2004). The course of PTSD, major depression, substance abuse, and somatization after a natural disaster. J. Nerv. Ment. Dis. 192, 823-829. doi: 10.1097/01.nmd.0000146911. 52616.22

Nukui, H., Midorikawa, S., Murakami, M., Maeda, M., and Ohtsuru, A. (2018). Mental health of nurses after the Fukushima complex disaster: a narrative review. J. Radiat. Res. 59(Suppl. 2), 108-113. doi: 10.1093/jrr/rry023

Ogińska-Bulik, N., and Juczyński, Z. (2016). Ruminacje a negatywne i pozytywne następstwa doświadczonych zdarzeń traumatycznych u ratowników medycznych. Med. Pr. 67, 201-211.

Ogińska-Bulik, N., and Kraska, K. (2017). Posttraumatic stress disorder and posttraumatic growth in HIV-infected patients - the role of coping strategies. Health Psychol. Rep. 5, 323-332. doi: 10.5114/hpr.2017.68017

Ogińska-Bulik, N. (2013). Negatywne i pozytywne skutki doświadczeń traumatycznych u pracowników służb ratowniczych - rola zasobów osobistych i społecznych. Med. Pr. 64, 463-472. doi: 10.13075/mp.5893.2013. 0048

Ogińska-Bulik, N. (2016). Zasoby osobiste a negatywne i pozytywne skutki doświadczeń traumatycznych u ratowników medycznych. Med. Pr. 67, 635-644. doi: $10.13075 / \mathrm{mp} .5893 .00409$

Parker, S. L., Sonnentag, S., Jimmieson, N. L., and Newton, C. J. (2020). Relaxation during the evening and next-morning energy: the role of hassles, uplifts, and heart rate variability during work. J. Occup. Health Psychol. 25, 83-98. doi: 10.1037/ocp0000155

Pedhazur, E. J., and Schmelkin, L. P. (1991). Measurement, Design, \& Analysis: An Integrated Approach. Hillsdale, NJ: Lawrence Erlbaum Associates.

Pietrzak, R. H., Schechter, C. B., Bromet, E. J., Katz, C. L., Reissman, D. B., and Ozbay, F. (2012). The burden of full and subsyndromal posttraumatic stress disorder among police involved in the World Trade Center rescue and recovery effort. J. Psychol. Res. 46, 835-842. doi: 10.1016/j.jpsychires.2012. 03.011

Przepiórka, A., Błachnio, A., and Siu, N. Y. (2019). The relationships between selfefficacy, self-control, chronotype, procrastination and sleep problems in young adults. Chronobiol. Int. 36, 1-11.

Rabelo, I., Lee, V., Fallah, M. P., Massaquoi, M., Evlampidou, I., Crestani, R., et al. (2016). Psychological distress among ebola survivors discharged from an ebola treatment unit in monrovia, liberia - a qualitative study. Front. Public Health 4:142. doi: 10.3389/fpubh.2016.00142

Rajkumar, R. P. (2020). COVID-19 and mental health: a review of the existing literature. Asian J. Psychiatr. 52:102066. doi: 10.1016/j.ajp.2020.102066

Ramaci, T., Barattucci, M., Ledda, C., and Rapisarda, V. (2020). Social stigma during COVID-19 and its impact on HCWs outcomes. Sustainability 12:3834. doi: $10.3390 /$ su12093834

Ranieri, J., Guerra, F., and Giacomo, D. (2020). Predictive risk factors for posttraumatic stress symptoms among nurses during the Italian acute COVID19 outbreak. Health Psychology Report doi: 10.5114/hpr.2020.101249

Roudini, J., Khankeh, H. R., Witruk, E., Ebadi, A., Reschke, K., and Stück, M. (2017). Community mental health preparedness in disasters: a qualitative content analysis in an iranian context. HDQ 2, 165-178. doi: 10.29252/nrip. hdq.2.4.165

Rybojad, B., and Aftyka, A. (2018). Trafność, rzetelność i analiza czynnikowa polskiej wersji Skali Dystresu Okołotraumatycznego [Validity, reliability and 
factor analysis of the polish version of the peritraumatic distress inventory]. Psychiatr. Pol. 52, 887-890. doi: 10.12740/PP/OnlineFirst/75122

Salovey, P., Mayer, J. D., and Caruso, D. (2002). "The positive psychologyof emotional intelligence," in Handbook of Positive Psychology, eds C. R. Snyder and S. J. Lopez (New York: Oxford University Press), 159-171.

Schwarzer, R. (ed.) (2015). Self-Efficacy: Thought Control of Action. Abingdon: Routledge.

Shultz, J. M., Cooper, J. L., Baingana, F., Oquendo, M. A., Espinel, Z., Althouse, B. M., et al. (2016). The role of fear-related behaviors in the 2013-2016 West Africa Ebola virus disease outbreak. Curr. Psychol. Rep. 18:104. doi: 10.1007/ s11920-016-0741-y

Sim, K., Choon Chua, H., Vieta, E., and Fernandez, G. (2020). The anatomy of panic buying related to the current COVID-19 pandemic. Psychiatry Res. 288:113015. doi: 10.1016/j.psychres.2020.113015

Sohrabizadeh, S., Tourani, S., and Khankeh, H. R. (2016). Women and health consequences of natural disasters: challenge or opportunity? Women Health 56, 977-993. doi: 10.1080/03630242.2016.1176101

Stellman, J. M., Smith, R. P., Katz, C. L., Sharma, V., Charney, D. S., Herbert, R., et al. (2008). Enduring mental health morbidity and social function impairment in world trade center rescue, recovery, and cleanup workers: the psychological dimension of an environmental health disaster. Environ. Health Perspect. 116, 1248-1253. doi: 10.1289/ehp.11164

Stueck, M. (2007). Development and Empiric Examination of an Intervention Programme Under the Use of Yoga and Biodanza for Occupational Stress. Leipzig: Faculty of Biomedical Sciences, University of Leipzig.

Stueck, M. (2009). The Stress Reduction Training with Elements of Yoga for Educators and Other burdened Professions (STRAIMY-Workbook). Strasburg: Schibri Publishing House.

Stueck, M., Delshad, V., Roudini, J., Khankeh, H., and Ranjbar, M. (2019). Health cube with school of empathy and stress reduction for iranian drivers: new tools for traffic psychology and biocentric health management in Iran. Mod. Care J. 16:e90632. doi: 10.5812/modernc.90632

Stueck, M., and Villegas, A. (2008). Dancing Towards Health? Empiric Research on Biodanza Biodanza in the Mirror of Sciences (Bd. 1). Strasburg: Schibri Publishing House.

Super, S., Pijpker, R., and Polhuis, K. (2020). The relationship between individual, social and national coping resources and mental health during the COVID19 pandemic in the Netherlands. Health Psychol. Rep. (in press). doi: 10.5114/hpr.2020.99028

Tsai, K. Y., Chou, P., Chou, F. H., Su, T. T., Lin, S. C., Lu, M. K., et al. (2007). Threeyear follow-up study of the relationship between posttraumatic stress symptoms and quality of life among earthquake survivors in Yu-Chi, Taiwan. J. Psychol. Res. 41, 90-96. doi: 10.1016/j.jpsychires.2005.10.004

Valdez, C. H. D., and Nichols, T. W. (2013). Motivating healthcare workers to work during a crisis: a literature review. JMPP 14, 43-51.
Vellingiri, B., Iyer, M., Narayanasamy, A., Govindasamy, V., Giridharan, B., et al. (2020). COVID-19: a promising cure for the global panic. Sci. Total Environ. 725:138277. doi: 10.1016/j.scitotenv.2020.138277

Vindegaard, N., and Benros, M. E. (2020). COVID-19 pandemic and mental health consequences: systematic review of the current evidence. Brain Behav. Immun. 89, 531-542. doi: 10.1016/j.bbi.2020.05.048

Wagner, D. D., and Heatherton, T. F. (2013). Self-regulatory depletion increases emotional reactivity in the amygdala. Soc. Cogn. Affect. Neur. 8, 410-417. doi: $10.1093 /$ scan/nss082

Wilder-Smith, A., and Freedman, D. O. (2020). Isolation, quarantine, social distancing and community containment: pivotal role for old-style public health measures in the novel coronavirus $(2019-\mathrm{nCoV})$ outbreak. J. Travel Med. 27:taaa020. doi: 10.1093/jtm/taaa020

World Health Organization [WHO] (1992). Psychosocial Consequences of Disasters: Prevention and Management. Geneva: World Health Organization.

Worldometers (2020). COVID-19 Coronavirus Pandemic. Available online at: https: //www.worldometers.info/coronavirus/?utm_campaign=homeAdvegas 1 ? (accessed on 12 June 2020)

Wu, P., Fang, Y., Guan, Z., Fan, B., Kong, J., Yao, Z., et al. (2009). The psychological impact of the SARS epidemic on hospital employees in China: exposure, risk perception, and altruistic acceptance of risk. Can. J. Psychiatry 54, 302-311. doi: 10.1177/070674370905400504

Xiao, H., Zhang, Y., Kong, D., Li, S., and Yang, N. (2020). The effects of social support on sleep quality of medical staff treating patients with Coronavirus Disease 2019 (COVID-19) in January and February 2020 in China. Med. Sci. Monit. 26:e923549. doi: 10.12659/MSM.923549

Xu, J., Xu, Q.-H., Wang, C.-M., and Wang, J. (2020). Psychological status of surgical staff during the COVID-19 outbreak. Psychiatry Res. 288:112955. doi: 10.1016/j.psychres.2020.112955

Zhang, W.-R., Wang, K., Yin, L., Zhao, W., Xue, Q., Peng, M., et al. (2020). Mental health and psychosocial problems of medical health workers during the COVID-19 epidemic in China. Psychother. Psychosom. 89, 242-250. doi: $10.1159 / 000507639$

Conflict of Interest: The authors declare that the research was conducted in the absence of any commercial or financial relationships that could be construed as a potential conflict of interest.

Copyright (c) 2020 Bidzan, Bidzan-Bluma, Szulman-Wardal, Stueck and Bidzan. This is an open-access article distributed under the terms of the Creative Commons Attribution License (CC BY). The use, distribution or reproduction in other forums is permitted, provided the original author(s) and the copyright owner(s) are credited and that the original publication in this journal is cited, in accordance with accepted academic practice. No use, distribution or reproduction is permitted which does not comply with these terms. 